\title{
|カーボンナノチューブの安全性
}

\section{Safeness of carbon nanotubes}

\author{
佐藤義倫 **, 横山敦郎 ${ }^{\star *}$, 柴田健一郎 **, 亘理文夫**, 田路和幸 *
}

Yoshinori Sato*,*, Atsuro Yokoyama**, Ken-ichiro Shibata**, Fumio Watari** and Kazuyuki Tohji*

\begin{abstract}
Carbon nanotubes (CNTs) have single- or multi-cylindrical graphene structures that possess diameters of a few nanometers, while the length can be up to a few micrometers. Single-walled carbon nanotubes (SWCNTs) and multi-walled carbon nanotubes (MWCNTs) possess a high tensile strength and ultra-light weight, and have excellent chemical and thermal stability. They also possess semiconducting and metallic conductive properties. These anomalous features have led to many proposed applications in the biomedical field, including biosensors, drug and vaccine delivery. However, CNTs could have unusual toxicological properties, in that they share intermediate morphological characteristics of both fibers and nanoparticles. This review presents the cytotoxicity and biocompatibility of CNTs. Finally, we report the activation of the human acute monocytic leukemia cell line THP-1 in vitro and the response in subcutaneous tissue in vivo to MWCNTs of different lengths.
\end{abstract}

\section{KEYWORDS : Carbon nanotubes, Cytotoxicity, Size effects, Biocompatibility, Inflammatory}

\section{1. はじめに}

近年,「組織工学」1),「再生医療」2) と呼ばれる新たな形の医療 が注目を集めている。再生医療の目的は, 従来の薬物療法や外科 療法では対処できないほど大きく損傷した生体組織や臟器を治 療することにあり,その最大の特徴は細胞を利用して生体組織を 再生, もしくは再構築する点にある。また, 自身の幹細胞から組 織を再生することが可能であれば, 拒絶反応を起こさないため, 次世代の治療法として期待が高まっている3)。このように再生医 療はこれまでとは大きく異なる新しいタイプの医療として注目さ れ, 医学, 生化学, 工学などの幅広い分野から研究が進められてい る。再生医療には大きく分けて 2 つの゙ループがあり, 1 つは生 体外 (in vitro) で組織を再構築して，それを移植するグループ2) と,もう1つは生体内 (in vivo) に执いて何らかの方法で生体のも つ自己修復能力を助けて組織を再生させるグループである3)。こ れらには生体親和性の材料が必要であるという共通点がある。生 体組織は細胞と細胞外マトリックスから成り立っており, 細胞の 分化・増殖には細胞外マトリックスがスカフォールド (足場)の 役割を果たしている。胎生期や組織の損傷が小さい場合には, 細 胞外マトリックスは自然に形成される。しかし, 誕生後何年か経 過してから組織に大きな欠損が生じると, スカフォールドを人為的 に提供しなければ細胞は増殖しにくく, 組織の再生も再構築も進 行しない。そのため再生医療には人工細胞外マトリックス (人工
スカフォールド) が必要であり,このための材料が生体材料, ある いはバイオマテリアルと呼ばれている32,4)。

スカフォールド用のバイオマテリアルには, コラーゲンのよう な天然高分子, 乳酸高分子のような合成高分子, ハイドロキシア パタイトのような無機物質などがある。これらの素材から繊維 状集合体やスポンジ体などの三次元多孔体スカフォールドが調 製される。緎維状物質は, 細胞が定着できる人工細胞外マトリッ クスの幾何構造の中でも増殖しやすい形状であると注目されて おり5), 近年, スカフォールド用のバイオマテリアルとしてカーボ ンナノチューブ (Carbon Nanotubes：CNTs）を用いる研究が行 われ始めている。炭素材料を生体材料に応用する試みはグラフ アイトが高血栓性に優れていることから始まり6), LTIカーボン (低温度等方性炭素材料) P C/C コンポジット (炭素繊維強化炭 素複合材料) を用いた人工心臟弁や人工歯根材 7) などの応用開発 が行われてきた。近年では,カーボンナノチューブ (Carbon Nanotubes ; CNTs) がもつ形状, ナノスペース, 大きな比表面積 などの特徵を活かし, 生体分子観察用プローブティップ8), 遺伝 子導入のベクター9)-16), 機能性糖鎖の吸着17)，18）によるドラッグ ターゲッティング材料, カテーテル材料 19), 抗原検出センサー20), 細胞培養担体 (スカフォールド) 21)-27) などの生体医療材料, 再生医 療材料として注目されている。再生医療においてCNTs はスカフ オールドとしての応用, つまり, 生体外あるいは生体内で細胞を 培養するための足場としてCNTs を利用するというもので, すで 
にいくつかの研究が行われている。Correa-Duarteらは垂直に配 向したCNTs でさまざまな三次元構造をもったスカフォールドを 調製し線維芽細胞培養実験を行った24)。またHuらは異なる官能 基を付加して表面電荷を変化させたCNTs を用いてスカフォール ドを調製し, 神経細胞培養実験を行った26)。その結果, CNTs ス カフォールドは細胞を育てる能力があることがわかった。さら にCNTs の電気特性を利用した電気刺激による神経細胞電気シグ ナル伝達の挙動の研究も行われている27)。また, 有機ナノチュー ブではあるが, Websterらはインプラント（歯根部の代替パーツ や人工関節など）に用いられるチタンに有機ナノチューブを被覆 させると, 被覆していないものよりも約 3 割多く骨芽細胞が付着 することを発見した28)。これはナノメートルサイズの凹凸が細 胞の付着を促進した結果であると報告している。さらに直径が 約 60nmのカーボンファイバー (Carbon Nanofiber : CNFs) 上に 選択的に細胞が成長することが報告されており,カーボン材料の 細胞に対する親和性が明らかになった29)。体内に埋め込まれる インプラントと元からある骨とがしっかり結合するためには, 骨 芽細胞がインプラント表面に迅速に付着することが非常に重要 であり，この結果はCNTsがインプラントと骨との結合を促進す る可能性があることを示していると考えられる。現にCNTs上の 骨芽細胞は増殖率が高いことが報告されている30)。これから到 来する高齢化社会では, 人工関節などのインプラントが大量に必 要になると予想され, 生体に迅速に結合するインプラントの必要性 はより大きくなると思われる。

CNTs はその特異な物性から, 分子電子デバイスや高感度セン サーなどのナノテクノロジー分野に大きな变革をもたらす潜在能 力をもつ新素材であり, 生産量も拡大しつつある。そこで, CNTs が人体や生物の体内に暴露される機会が増加する前に, あるいは CNTs を生体材料として応用する前に, これらが人体に取り込まれ たときの生体反応をより詳しく調べる必要性が生じている31)-35)。 CNTs が人体に取り込まれる可能性は大きく2つに分類される。 1 つはCNTs 扱う作業者や研究者であり, もう1つはCNTsを生 体材料として使用される患者である。両者に共通していること は, 生体外のもの (CNTs) が細胞と相互作用する機会が生じること である。一般的に細胞毒性を引き起こす要素は, 金属溶出 ${ }^{36), 37), ~}$ 表面官能基 38)-40), 比表面積, サイズ効果 41)-46), 粒子溶解度47) が知

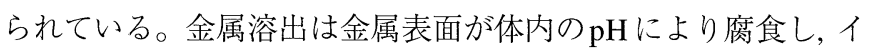
オンとして溶出することによって細胞に影響を与える。細胞や 組織内での金属腐食は最も知られた細胞毒性を引き起こす要素 であり, 金属のイオン化傾向に依存すると言われる。インプラント 材料である $\mathrm{Ti}$ 合金 (Ti-6Al-4V)の Al はしばしば溶出し48), 骨の 成長阻害因子やアルツハイマー病の発症因子の原因として挙げ られており 49), またVの溶出は強い細胞毒性をもつ元素である。 生体親和性をもたせるために, 材料の表面修飾は一般的な処理で あるが, 官能基の種類により毒性を示すことが報告されている。 例えば, 細胞標識として注目されている $\mathrm{CdSe}$ 量子ドットの表面 改質による細胞毒性評価では, $\mathrm{COOH} / \mathrm{OH}$ が混在した表面コーテ イングは毒性を示さず, $\mathrm{COOH}$ のの表面修飾は毒性を示すと報
告されている39)。比表面積の効果は, 比表面積が大きければ大き いほど, 材料と細胞との接触する面積は大きくなり, 材料と細胞 の相互作用が大きくかかわる細胞毒性を左右する要因となる。同 時に粒子のサイズ, 形状も細胞毒性に影響を与え, 例えば, 生体界 面活性剂で被覆された金粒子は生体親和性があるが40)，小さい サイズの金ナノ粒子は電子状態の変化から, 被覆された生体界面 活性剂が外れ, DNAに吸着して安定化し, その吸着されたDNA は正常に働かず, 毒性を引き起こすと報告されている46)。また, ナノ粒子の生体影響を考えるときに粒径がきわめて小さくなる と, ナノ粒子表面の物理 ·化学的性質と細胞との相互作用, ナノ 粒子の体内挙動が問題となってくる。一般に生体親和性の高い テフロン41)やチタン 42),45) もナノサイズになると肺毒性, 細胞毒性 を示すことが知られている。一方, 細胞毒性には形状効果もあり, アスベストは大きな縦横比をもつ繊維状の物質で悪性中皮腫や 肺癌を発現する物質である50)。1970年代に米国の Stanton ${ }^{51)}$ と 西ドイツのPott ${ }^{52}$ ) は独自に繊維状形態に着目し, サイズ (長さ, 直 径)を調製したさまざまな物質をラットやマウスの胸腔, 腹腔に 注入し長期間飼育後, 胸腔, 腹腔の病変や悪性中皮腫の発現率を調 べている。その結果, 生体内で耐久性があり, 細くて長い繊維状 物質は化学組成や結晶構造に関係なく発ガン性をもつことを示 し, 特に幅 $0.25 \mu \mathrm{m}$ 以下で, 長さ $8.0 \mu \mathrm{m}$ 以上の繊維の中皮腫発現率 が最も高いことを見出している。Hartらもアスベストや人工ガ ラス状ファイバーの長さ, 直径, 組成などの要因について詳細に 報告している53)。

単層カーボンナノチューブ (Single-Walled Carbon Nanotubes ; SWCNTs), 多層カーボンナノチューブ (Multi-Walled Carbon Nanotubes ; MWCNTs) は（高純度グラファイト棒を陽極として アーク放電法により合成される陰極堆積物中の多層カーボンナ ノチューブを除く)すべて触媒金属を用いることにより合成され る。現在ではその触媒金属は, Fe, Co, Ni, Y, La, Ce, YNi, FeNi, $\mathrm{CoNi}, \mathrm{CoMo}$ な゙と単体金属から合金まで数多く知られている。 したがって, 金属触媒を用いて合成されるため, 合成直後のカー ボンナノチューブ (as-grown CNTs) には金属粒子が含まれてい る。また, CNTsは応用に応じてさまざまな機能性官能基を化学 修飾することが可能であり, 比表面積も大きい。さらに䋐維状で あり, 直径, 長さ, 形態もさまざまである。このように細胞毒性を 引き起こすと考えられる要因を所有するCNTsの細胞毒性を調べ ることは必要不可欠である。ここでは, 現時点で報告されている CNTs の安全性についてまとめ, 著者らのグループが行った「高 純度多層カーボンナノチューブの長さに対する細胞毒性評価」に ついて記述する。

\section{2. カーボンナノチューブの安全性評価}

2001 年, Huczko らは54) 未精製のCNTs（アーク放電法により 合成; 金属触媒 $\mathrm{Co} / \mathrm{Ni}, \mathrm{SWCNTs}$ あるいはMWCNTs なのかは記

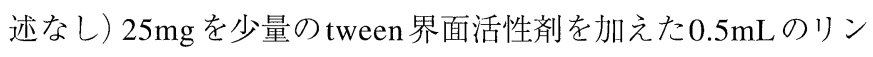
酸緩衝生理食塩水に分散させ, モルモットの気管内に注入し, 肺 毒性試験を行っている(コントロールはCNTsなしの溶液)。気 
管支肺胞洗浄液試験からの炎症性細胞数はコントロール（比較対 照サンプル) との違いが観察されず, 特に毒性はないと報告して いる。しかし, 2005 年彼らは55) 再度, 未精製MWCNTs (CVD 法, アーク放電法), 販売しているMWCNTs (CVD 法; NanoLab 社, Pyrograf社, 昭和電士) をモルモットの気管内に注入し, 気管支肺 胞洗浄液試験, 肺抵抗試験, 組織学的顕微鏡観察を 3 力月後に行 った。Pyrograf社以外のMWCNTsは気管支肺胞洗浄液に肺胞マ クロファージを確認している。また, 異常な肺抵抗を示し, 組織 学的観察からは多種の損傷か観察されたと報告しており,2001年 のデータとは逆の結果を示している。

Warheit らは56), $1.0 \%$ tween 界面活性剤の添加された生理食塩 水に未精製のSWCNTs（レーザー蒸発法により合成; 金属触媒 $\mathrm{Co} / \mathrm{Ni})$ を $1.0 \mathrm{mg} / \mathrm{kg}$ と $5.0 \mathrm{mg} / \mathrm{kg}$ となるように調製し,ラットの気 管内に注入し, 気管支肺胞洗浄液試験, 細胞增殖アッセイ, 組織学 的観察を 24 時間後, 1 週間後, 1 力月間後, 3 力月間後に行ってい る。気管支肺胞洗浄液試験, 細胞增殖アッセイから, 一時的な炎 症を観察し, 組織学的観察からは多発性肉芽腫を観察しているが, 濃度依存性がなく, 進行的な炎症ではないと報告している。

Lam らは57), マウスの血清 $50 \mu \mathrm{L} に 0.1 \mathrm{mg}, 0.5 \mathrm{mg}$ の未精製 SWCNTs (HiPco), 精製SWCNTs (HiPco) (CVD 法の1種である HiPco 法により合成; 金属触媒 Fe), 未精製SWCNTs (アーク放 電法により合成；金属触媒 $\mathrm{Ni}$ ）を調製し，マウスの気管内に注入 し, 組織学的観察を 1 週間後, 3 力月間後に観察した。組織学的観 察から, すべてのサンプルは濃度依存性を示し, 肺組織損傷が観 察されている。特にNi触媒で合成された未精製SWCNTs は死亡 率が高いと報告している。これは触媒金属 $\mathrm{Ni}$ の影響が現れてい ると考えられる。

Mullerらは58), 精製MWCNTs と精製MWCNTsの粉砕物を調 製し, $0.5 \mathrm{mg}, 2.0 \mathrm{mg}, 5.0 \mathrm{mg}$ をラットの気管内に注入し, 気管支肺 胞洗浄液試験, 生体内滞留性, 組織学的観察を 2 力月後に行って いる。どちらのCNTs も濃度依存性を示し, 炎症と肉芽腫の形成 が観察されている。炎症はカーボンブラックより強く, アスベス トより弱く, どちらのCNTsも60日後でも肺に滞留しているが, 精製MWCNTsのほうが精製MWCNTsの粉砕物と比較して滞留 物として残りやすいことを指摘している。

Huczko らは59), 未精製MWCNTsの水溶液を飽和させたフィ ルターペーパーを皮膚に接触させてアレルギー反応を試験した (パッチ試験)。接触時間は96 時間で, 被験者はアレルギーの感 受性が高い 40 人の志願者で行っている。さらに, 未精製MWCNTs の水溶液をウサギの目に滴下する眼滴試験による炎症性を調べ ている。どちらのテストも MWCNTsの混入しているコントロー ルと比較して違いか観察されず, 毒性がないと結論している。

Shvedovaらは60), 不死化したヒト表皮ケラチノサイト細胞株 HaCaT 細胞に関する未精製SWCNTs (CVD法, 触媒金属; Fe) の影響を調べている。SWCNTs は培養液に0.06, 0.12, $0.24 \mathrm{mg} / \mathrm{mL}$ の浱度に調製し, ヒト由来表皮細胞と混合して18時間培養した。 その結果, ラジカル種と過酸化物が増加し, 同時に細胞生存率の 減少, 細胞組織の炎症を確認している。しかし,これらの影響は
高濃度金属触媒 $\mathrm{Fe}$ の影響であると結論づけている。

Monteiro-Riviereらは61)，ヒト表皮細胞に関する竹の子構造をも つ精製MWCNTs (CVD法)の影響を調へている。精製したMWCNTs は培養液に0.1, 0.2, 0.4mg/mLの濃度に調製し, ヒト由来表皮細 胞と混合し24時間培養した。MWCNTsはサイトカイン（細胞の 分泌物) であるIL-8 (インターロイキン 8 ; 急性期炎症反応にお ける好中球遊走, 活性化にかかわる本質的な因子) を誘発し, 細 胞生存率が減少することを時間依存性, 濃度依存性試験から確認 している。透過型電子:顕微鏡 (TEM) から細胞内にMWCNTs が 存在することも観察している。この精製MWCNTsの試験から， ヒト表皮細胞に対してMWCNTsは毒性を示すと考察している。

Mullerらは58), 精製MWCNTs と精製MWCNTs の粉砕物を調 製し, $20,50,100 \mu \mathrm{g} / \mathrm{mL}$ の濃度を腹膜マクロファージ (マクロフ アージ；異物を領食する食食細胞）を用いて2力月間生体外試験 (in vitro) を行っている。細胞毒性は乳酸脱水素酵素放出（培養 24 時間後), 炎症性はTNF- $\alpha$ のRNA 発現 (培養 6 時間後) を測 定して評洒している。彼らは精製MWCNTsの粉砕物はアスベス トやカーボンブラックと同様な濃度依存性を示す毒性があると 報告している。また, 精製MWCNTsにおける TNF- $\alpha$ のRNA 発現や炎症は, 精製MWCNTs の粉砕物のものに比べると低く, 重 大な毒性を示さないと言及している。また彼らは, 過酸化水素水 やギ酸を加えた精製MWCNTs 分散液は活性酸素やラジカル種を 発生させないこと, 多くの水酸基活性ラジカルや活性酸素ラジカ ルを補足するという“スキャベンジャー効果”があることを見出 して抢り 62), 逆にラジカル種を補足する効果により, 免疫系のバ ランスを崩す可能性が起こり得ることを指摘している。

Bottiniらは63), 未精製MWCNTs (CVD法; NanoLab社製) と 親水処理した精製 MWCNTs をそれぞれ $40 \mu \mathrm{g} / \mathrm{mL}, 400 \mu \mathrm{g} / \mathrm{mL}$ の 濃度に調製し, ヒトT細胞の細胞生存率, 細胞增殖率, 細胞死亡率 を測定している。彼らのCNTs 毒性の投与量評価によれば, $40 \mu \mathrm{g} / \mathrm{mL}$ (細胞 1 つ当たりに1.0ngの量) 以下のCNTs は毒性がな く, 生体医学応用に使用可能なCNTs投与量であると推測しており, その毒性は物理的な要素 (形状, 直径, 長さ, 吸着特性) に依存寸 ることも言及している。

上記からもわかるようにさまざまな CNTs をさまざまな处理を 施して毒性試験に使用している。同時に細胞も多種多様である ことから, 得られるデー夕も十人十色である。本来のCNTsの毒 性を評価するにあたり，上記の論文では細胞毒性にかかわる4つ の基礎的な要因 (金属含有濃度, 表面官能基, サイズと形態, 比表 面積)に関するCNTsの詳細な分析が久けている。そのため, 現 時点ではナノチューブの毒性がどのような要因から引き起こされ ているか議論できないのが現状である。しかしながら,これまで の報告からも明らかにas-grown CNTsは, 細胞に対する金属溶出 の影響があるため, 毒性を引き起こしている。したがって, 生体 材料などへCNTs 応用するには, 十分に触媒金属を除去したも のでなければならないことは必須であると言える。

一方, CNTsが細胞毒性を示す報告ばかりではない。Koyama らは64), 素性の知れた4つの異なるCNTs (SWCNTs, 直径の異な 
るMWCNTs，カップ型MWCNTs）を末梢血中T細胞のCD4+と $\mathrm{CD} 8+の$ 测定，また皮下細胞に埋入したときの周罒軟組織の炎症 反応 (3カ月間) を病理組織学的に調べているが, アスベストと比 較すると格段に低い細胞毒性を示している。

Chlopekらは65), 高純度MWCNTsに対する線維芽細胞, 骨芽 細胞, オステオカルシンの細胞生存率と IL-6, 活性酸素放出量な どのサイトカイン分泌量を調べている。彼らのデータもわずか なサイトカイン量の増加が観測されているが, 医療に使われている ポリサルフォンと同様に生体親和性材料であると報告している。

Sayesらは66), in vitroでヒト由来真皮線維芽細胞を使用し, SWCNTs の細胞毒性における官能基の化学修飾度の影響を調へ ている。SWCNTs はSWCNT-phenyl-SO $\mathrm{S}_{3} \mathrm{H}$, SWCNT-phenyl$\mathrm{SO}_{3} \mathrm{Na}\left(\mathrm{SWCNTs}\right.$ に対する-phenyl-SO $\mathrm{S}_{3} \mathrm{X}$ の化学修飾度は $\mathrm{C} / \mathrm{CF}=$ 18，41，80。C/CFは化学修飾された官能基に対する SWCNTsの 割合を示す。数值が低いほど化学修飾度が高い), SWCNT-pheny1$(\mathrm{COOH})_{2}\left(\mathrm{SWCNTs}\right.$ に対する-phenyl- $(\mathrm{COOH})_{2}$ の修飾度は $\mathrm{C} / \mathrm{CF}=23), 1.0 \%$ プルロニック F108被覆したSWCNTs を使用 している。彼らはSWCNTsの化学修飾度が増加すると, 界面活 性剂で被覆したSWCNTsよりも大幅に細胞毒性が低いことを見 出している。化学修飾 SWCNTs の修飾度に対する細胞生存率は $50 \%$ 未満にはならないと報告している。

Bianco らも 67), 68), 化学修飾したSWCNTs, MWCNTs の生体 親和性を報告している。111Inラベルしたジエチレントリアミン 五酢酸を化学修飾したSWCNTs を静脈内投与し，ガンマシンチ グラフィーで観察している。透過型電子顕微鏡で排出された尿 中にSWCNTs, MWCNTsが観察されたことから, 化学修飾した SWCNTs, MWCNTs は肝臓や脾臓などの網内系臓器には蓄積せ ず, 血液循環から腎排泄を通り, 尿として排出されることを推定 している67)。一方, in vitroに抢いて, 4つの化学修飾したSWCNTs

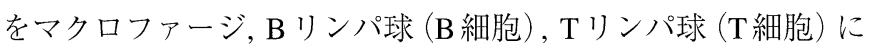
取り込まれているが, 細胞生存率には影響はなかった。溶解度の 高い化学修飾したSWCNTs はそれぞれの免疫系細胞の機能は正 常に保ったままであり,やや溶解度の低い化学修飾したSWCNTs は, マクロファージによる炎症性サイトカインの分泌を引き起こ してはいるものの, リンパ球の機能が保たれていることを確認し ている68)。

Chen らは69), CNTs 表面を糖重合体でコーティングさせるこ とにより生体親和性を高め, カーボンナノチューブに基づいた生 体組織工学スカフォールドの作製を試みている。

\section{3. 高純度多層カーボンナノチューブの細胞毒性に関する 長さの影響}

CNTs は值径数ナノメートル, 長さ数〜数十マイクロメートル の非常に大きな縦横比をもった物質であり,カーボンファイバーと ナノ粒子の中間のサイズである。CNTsの細胞に及ぼす影響につ いて報告されてきているが, 高純度に精製された長さの異なる CNTs が細胞に与える影響を調べた研究例はこれまでに報告され ていなかった。本項では著者のグループが行った「高純度多層カ
ーボンナノチューブの練胞毒性に望する長さの影響」について述 ベる。

一般的に細胞毒性の調べ方にはいくつかの方法がある。第1は 対象物を加えた状態で細胞を培養し, 生存している細胞数を顕微 鏡で数える力法である。この方法は確实ではあるが, 于数がかか るため, 通常は生化学的な方法で代用する。細胞が生きていれば 細胞本来の代謝作用によって外部の物質を取り込んで, 細胞人の 酵素作用によって化学変化を与える。それを利用して代謝され やすい色素を培地に加えて, 吸収 (または蛍光) スペクトルの変 化から細胞活性を求める方法である。さらに高度な方法として, 細胞が刺激を受けたときに放出する紲胞間のシグナル伝達物質 などを測定する方法もあり,この方法では細胞が破壞されるような 強い毒性だでなく, その前段階の刺激性を評価することも可能 である。上記のいくつかの検証方法を用いてMWCNTsの長さの 違いが細胞にどのような影響を及ぼすのかを明らかにするため に, 厳密に高純度精製された長さの異なるMWCNTsのヒト由来 マクロファージ系細胞株である THP-1 細胞に及ぼす影響 (in vitro) と,ラット胸部皮下細胞に埋入したときの周囲軟組織の炎症反応 (in vivo) を病理組織学的に調べた70)。

\section{1 材料と実験方法}

合成直後の MWCNTs (NanoLab 社製, 米国) 100mg 大大気中, $773 \mathrm{~K}, 90$ 分間燃焼酸化させた後, 6M-HCL 1.0 Lに入れ, 333Kで 12 時間静置させた。その後, $3 \mathrm{M}-\mathrm{NaOH} 1.0 \mathrm{~L}$ に入れ, アルミナを 除去した。ろ液が中性になるまで熱水でろ過して洗い, 万過物を 大気中, $333 \mathrm{~K} て ゙ 24$ 時間乾燥させた。精製したMWCNTs100mg を濃硫酸 $(95 \%)$ : 濃硝酸 $(60 \%)=75 \mathrm{~mL} ： 25 \mathrm{~mL}$ の混合液 $100 \mathrm{~mL}$ に入れ, 5 時間超音波照射 $(200 \mathrm{~W}, 39 \mathrm{kHz})$ を行った71)。その後, 切断処理したMWCNTs $10 \mathrm{mg}$ をエタノール $1000 \mathrm{~mL}$ に分散させ, $37 \mu \mathrm{m}$ のメッシュフィルターで凝集しているナノチューブをろ過 した。次にポアサイズ $2.0,1.2,0.8,0.4 \mu \mathrm{m}$ のポリカーボネートメ ンブランフィルターの順番でろ過を行い, それぞれのフィルター 上のケークを真空中, $313 \mathrm{~K}, 48$ 時間以上乾燥させた。この処理を 3 バッチ行った。MWCNTsによるTHP-1 細胞の活性化は in vitro で以下の手順で行った。U型の96穴のマイクロプレートを用い て, その 1 ウェルに $10 \%$ ヒト由来の血清を含むRPMI 1640 培地 $200 \mu \mathrm{L}$ 中に $5.0 \times 10^{5}$ 個の THP- 1 細胞を懸濁させ, MWCNTs 懸濁 液 $5 \mathrm{ng} / \mathrm{mL}, 50 \mathrm{ng} / \mathrm{mL}, 500 \mathrm{ng} / \mathrm{mL}$ の濃度でそれぞれ16時間刺激し た。遠心により上澄みを集め, ELISA 法でサイトカインである腫 瘍壊死因子量（Tumor Necrosis Factor-alpha：TNF- $\alpha$ ）を測定し た。周井軟組織の炎症反応 (in vivo) は以下の方法で行った。粉 体サンプルを 8 週齢雄性ウィスター系ラットの胸部皮下に埋入し, 1,4 週後に灌流固定後, 摘出し光学顕微鏡および透過型顕微鏡 (TEM）で観察した。（詳しい細胞毒性実験の記述は文献 70, 72 を参照)

3.2 高純度多層カーボンナノチューブのキャラクタリーゼーシ ヨン

MWCNTsは, NanoLab 社から購入したものを使用した。形態 は曲がりくねった繊維状であり, 外径 $10 \sim 20 \mathrm{~nm}$, 長さ $1.0 \sim 3.0 \mu \mathrm{m}$ 

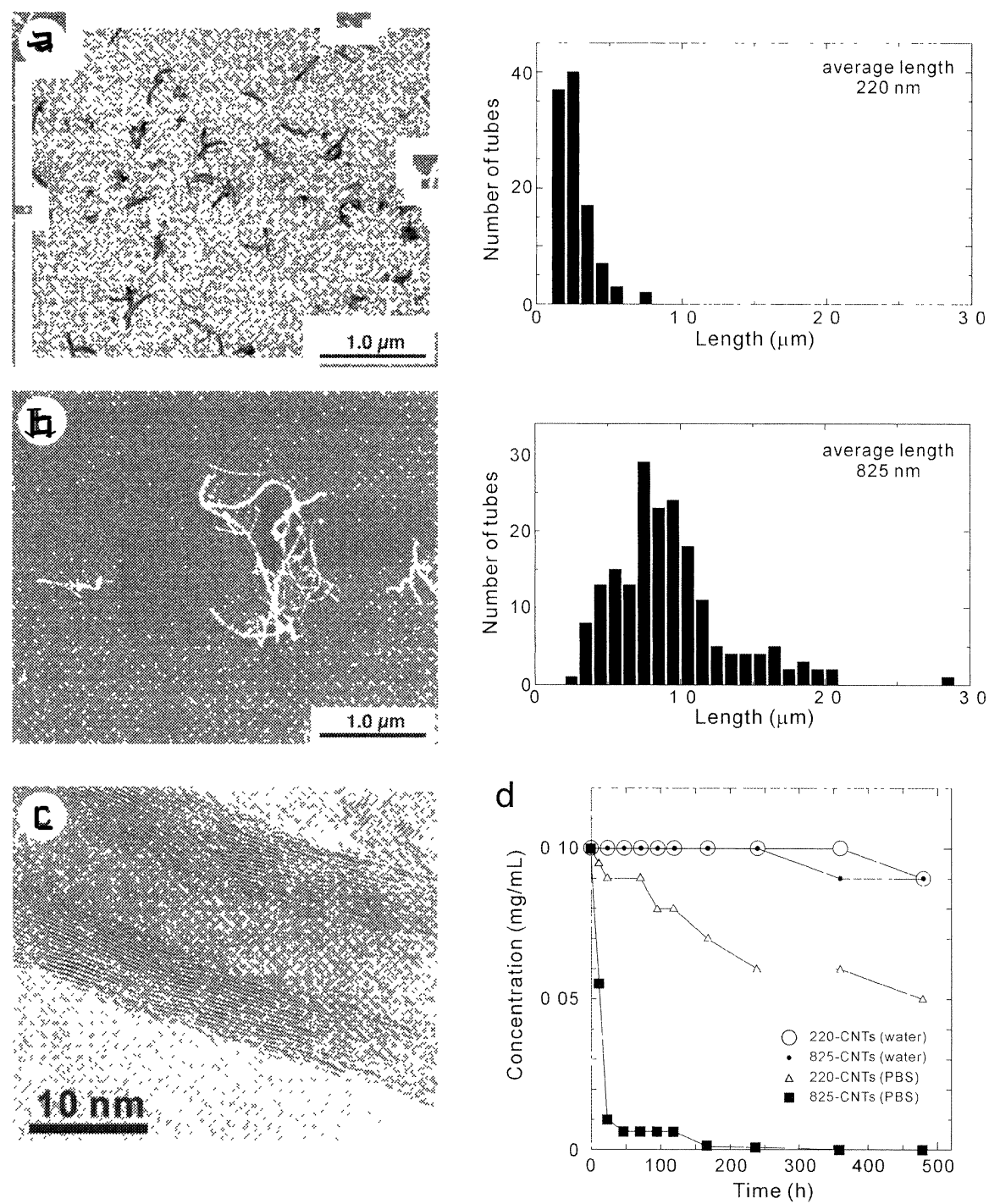

Fig.1 SEM (left) and size-distribution (right) of 220-CNTs (a) and 825-CNTs (b). (c) TEM photographs of 220-CNTs. (d) CNT concentration versus time plots for both 220-CNTs and 825-CNTs dispersed in water and PBS ; 220-CNTs in water $(\bigcirc)$, 825-CNTs in water $(\bullet)$, 220-CNTs in PBS $(\square)$ and 825-CNTs in PBS ( $\square)$, respectively.

と広範囲にわたって分布している。MWCNTs中の金属濃度は誘 導結合高周波プラズマ分光分析 (ICP-OES) 測定から見積った。 ICP-OES 測定では, 測定試料を溶液としてアルゴンプラズマ中に 導入するため, 固体試料を酸などで分解して溶液とする必要があ り, 試料の組成を損失することなくまた，いかに効率良く溶液化 できるかが問題になる。CNTs 試料の溶液化法として, 酸分解法, 灰化／酸分解法, 灰化/融解法, 直接融解法, マイクロウェーブ加 圧分解法の検討を行った結果, 操作性, 定量值精度に優れている マイクロウェーブ加圧分解法により, CNTs 試料の溶液化した73)。 CNTs中にMoが含有されている場合には, 溶液化方法に注意し なければならない。灰化／酸分解法, 灰化／融解法での灰化時に $\mathrm{Mo}$ の一部が $\mathrm{MoO}_{3}$ (融点：1068K) となって昇華するため, Mo の濃度が低く見積られてしまう。近年ではMo系金属触媒による ナノチューブ合成法が増えており, 購入も可能となっているため, Mo 金属濃度の見積もりには注意されたい。今回使用した精製前 のサンプルの元素組成はC $: 88.50 \mathrm{wt} \%, \mathrm{Al}: 5.73 \mathrm{wt} \%, \mathrm{Fe}$ ：
$4.43 \mathrm{wt} \%, \mathrm{Mo} ： 1.27 \mathrm{wt} \%, \mathrm{Cr} ： 0.07 \mathrm{wt} \%$ あ゙った。この $\mathrm{Al}$ $\mathrm{Al}_{2} \mathrm{O}_{3}$ の微粒子であることをTEM-EDXにより確認した。これに 対して精製したサンプルの元素組成は C : $98.17 \mathrm{wt} \%, \mathrm{Al}$ ： $1.41 \mathrm{wt} \%, \mathrm{Fe}: 0.26 \mathrm{wt} \%$, Mo : $0.01 \mathrm{wt} \%, \mathrm{Cr} ： 0.15 \mathrm{wt} \%$ であり, 高純度であることがわかった73)。Crの割合が高くなっているの は, ナノチューブ切断処理の硝酸により, Cr内包炭素カプセルの 炭素が湿式酸化され，内包金属の $\mathrm{Cr}$ の表面が不動態を形成した ためと考えられる。残存している金属はグラファイトカプセル で被覆されていることを精製後のTEM写真から確認している。

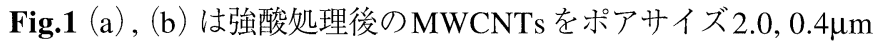
のメンブランフィルターでろ過したときのケークのSEM写真 (左)である。右図はそれぞれのポアサイズで分離したMWCNTs の長さ分布である。MWCNTs の平均長さは $825 \mathrm{~nm}, 220 \mathrm{~nm}$ であ った (以後, $220 \mathrm{~nm}$ の MWCNTs を220-CNTs, $825 \mathrm{~nm}$ の MWCNTs を 825-CNTs とする)。Fig.1 (c) は平均長さ $220 \mathrm{~nm} の$ MWCNTs のTEM写真である。MWCNTsの切断処理により, 外側層がダメ 


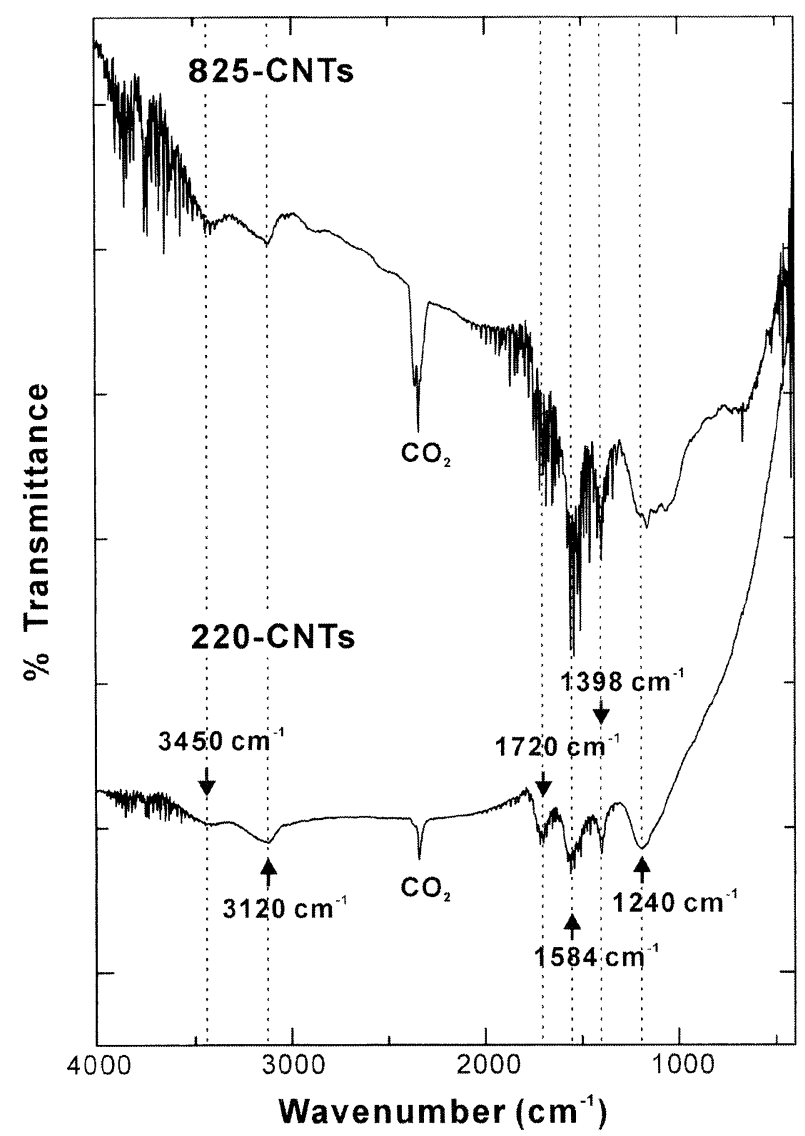

Fig.2 IR spectra of 220-CNTs (bottom) and 825-CNTs (top).

ージを受けていることがわかる。Fig.1 (d) は220-CNTs と825CNTs の蒸留水中とリン酸緩衝生理食塩水 (PBS) 中の時間に対 する濃度変化を示した。蒸留水中では, どちらのチューブもよく分 散しており, 沈殿は観察されなかった。一方, PBS 中では, 825CNTs のほうが早期に沈殿を起こすことがわかった。Fig.2は220CNTs と 825-CNTs の赤外線吸収スペクトルである。1584 $\mathrm{cm}^{-1}$ は芳香族の $\mathrm{C}=\mathrm{C}$ に由来する伸縮振動で, $1398 \mathrm{~cm}^{-1}$ と $1240 \mathrm{~cm}^{-1}$ はカルボキシル基のC-O伸縮振動と O-H の変角振動に相当する。 これらのバンドはカルボキシル基のダイマー (2 量体)を形成す ることで高波数に現れることが明らかにされている。また， $1398 \mathrm{~cm}^{-1}$ と $1550 \mathrm{~cm}^{-1}$ のショルダーピークは伸縮振動のカルボ キシルアニオンと推定される。 $3120 \mathrm{~cm}^{-1}$ と $3450 \mathrm{~cm}^{-1}$ はカル ボキシル基の $\mathrm{O}-\mathrm{H}$ 伸縮振動である。このように $\mathrm{H}_{2} \mathrm{SO}_{4} / \mathrm{HNO}_{3}$ 溶 液処理によりカーボンナノチューブにはカルボキシル基が付加し ていることが推定される。

\subsection{In vitro 試験}

マクロファージ系THP-1 細胞は異物と認識すると, 活性化され, 炎症性サイトカインのTNF- $\alpha$ を生産する。Fig.3は220-CNTs と 825-CNTs の THP-1 細胞の活性化されて生産したTNF- $\alpha$ 量を表 した棒グラフである。参照サンプルである微生物由来のPathgenAssociated Molecular Pattern (PAMP) をもつリポペプチドはマ クロファージを活性化し, TNF- $\alpha$ を生産していることから, 細胞 に異物として認識されていることがわかる。一方, 220-CNTs と 825-CNTs はマクロファージの活性化能を発現しているが, その

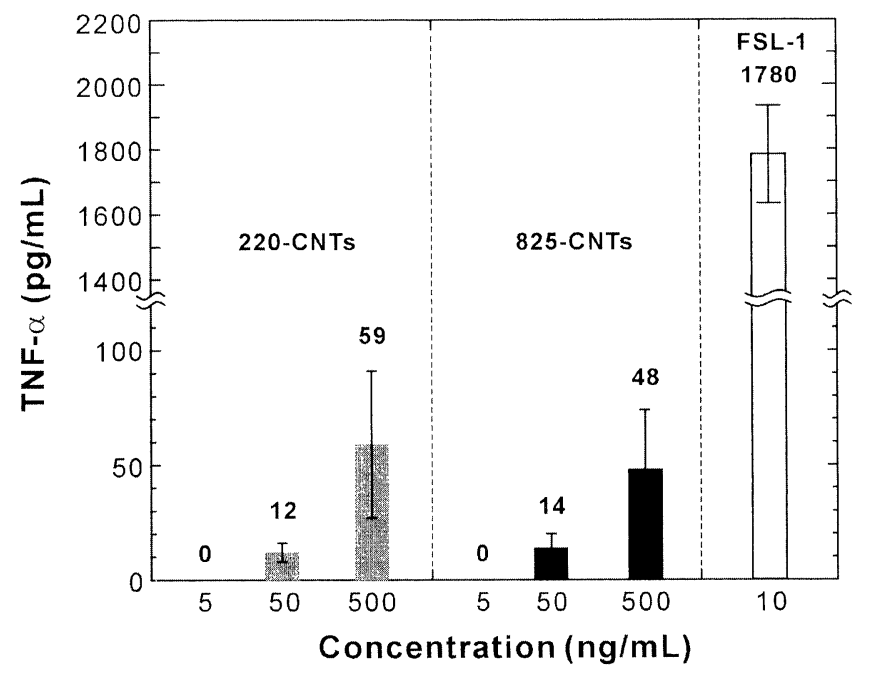

Fig.3 Induction of THP-1 cells by 220-CNTs and 825-CNTs. The diacylated lipopeptide FSL-1 was used as a positive control.

活性は非常に低いことがわかった。それぞれのサイズ分離した MWCNTs の濃度依存性では, 濃度が高くなると TNF- $\alpha$ が増加する 濃度依存性を示しているが, その量は非常に低い。また, 濃度一 定に対するMWCNTsのサイズ依存性では, TNF- $\alpha$ の量がほとん ど変化せず,リポペプチドの TNF- $\alpha$ 量の約 $1 / 45 \sim 1 / 60$ 倍であっ た。細胞毒性の要素には, 異物の表面積, 官能基が関係すると言 われている。使用した220-CNTs と825-CNTs の比表面積は $300 \mathrm{~m}^{2} / \mathrm{g}, 320 \mathrm{~m}^{2} / \mathrm{g}$ と大差がなく,また, MWCNTs の表面はカルボ キシル基で修飾されているので（ただし，それぞれのチューブに 修飾されているカルボキシル基の量は測定していない), 細胞への 親和性が十分高いと考元られる。これらの要素はナノチューブ の長さが異なることによる大きな変化はなく,このTHP-1 細胞の in vitro 試験では, 220-CNTs と 825-CNTsのサイズの影響が明確 に現れなかった。

\subsection{In vivo 試験}

\subsection{1 平均長さ $220 \mathrm{~nm}$ の MWCNTs}

埋入 1 週間後では $220-\mathrm{CNTS}$ の多くがマクロファージや線維芽 細胞内に観察され，大きな集塊周囲には異物巨細胞が観察された が, 強い炎症反応は観察されなかった (Fig.4a, 光学顕微鏡写真)。 TEM観察に拀いて, 220-CNTsはマクロファージ中のライソゾー 厶内に観察され, 短いMWCNTsが㠜集している様子が確認でき た。ナノチューブの形態に大きな恋化は認められなかった。4週 間後でも220-CNTs の多くは1 週間後のものと同様で, 特に大き な変化は認められなかった $($ Fig.4c, Fig.5a, c)。

\subsection{2 平均長さ $825 \mathrm{~nm}$ のMWCNTs}

埋入 1 週間後の $825-\mathrm{CNTS}$ の多くは, ナノチューブ周囲に軽度 の炎症反応を伴う肉芽組織か観察された。これは220-CNTs と比 較するとやや強い炎症反応を示している。一部はマクロファー ジに領食されているものの, ほとんど多くは細胞質内に凝集してい た (Fig.4b, 光学顕微鏡写真)。TEM 観察に执いて, 多くの825CNTs は, 絡み合った凝集状態が観察され, 膜構造で覆われず, 細胞 質内に集塊していた。埋入4週間後では, いわゆる肉芽腫性炎の 
状態を呈しており,ナノチューブの周囲にはマクロファージや異 物下.細胞などの䕘食細胞が数多く観察される $($ Fig.4d, 光学顕微 鏡奂真)。一部はマクロファージに貪食されていたが, 多くは細

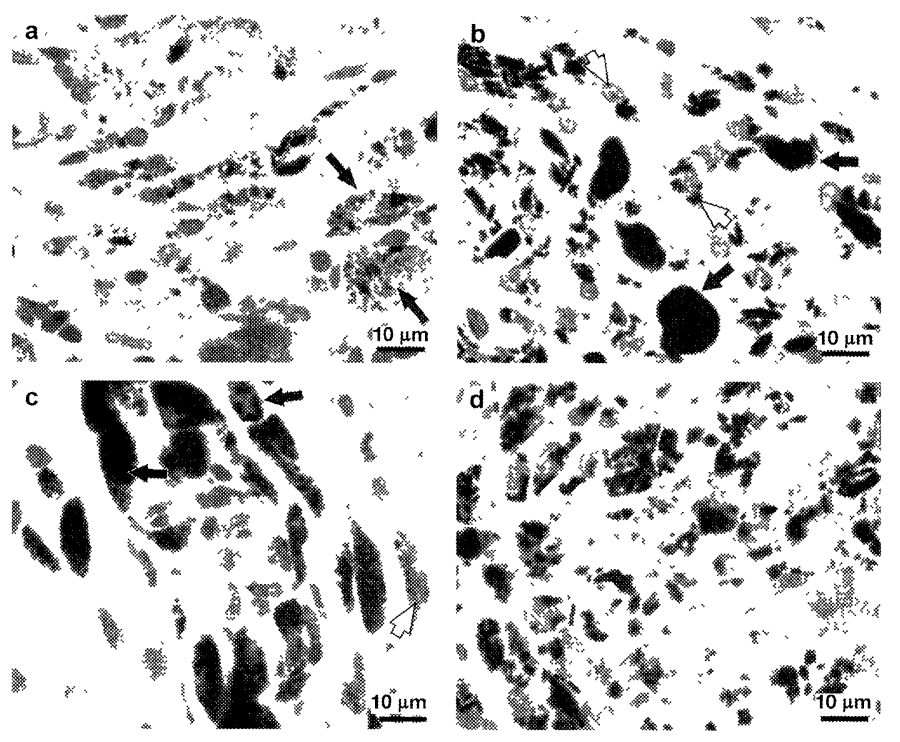

Fig.4 Histology of 220-CNTs and 825-CNTs implanted in the subcutaneous tissue. 1 week : Clusters of both of 220-CNTs and 825 -CNTs were surrounded by granulation tissue. (a) Many of the 220-CNTs were enveloped by macrophages (arrows). (b) Some of the 825-CNTs were observed in the intercellular space (arrows), while others were observed in macrophages (white arrows). 4 weeks : (c) Most of the 220CNTs were observed in macrophages (arrows) and fibroblasts (white arrows). (d) There was a negligible difference in the degree of inflammation around 825-CNTs 4 weeks following surgery, compared to 1 week. All scale bars are $10 \mu \mathrm{m}$.
胞質内に存在し, 膜構造は認められない $($ Fig.5b, d, e )。今回の実 験では, 1 本 1 本のMWCNT はマクロファージが䕘食され, 細胞内 に取り达まれる長さではあるが, 試験方法がMWCNTs のパウ ダーで埋入するため, 埋入時からすでにMWCNTsは凝集状態で ある。生理活性水などのナトリウムイオンやカリウムイオンが 溶解している電解質では, カルボキシル基をもつナノチューブ は凝集する特性をもつ74)。また, PBSでは, 825-CNTsのほうが 220-CNTsより速く凝集する効果がある（Fig.1d）。したがって， 凝集状態で導入された825-CNTs は軟組織内で分散することが困 難で, マクロファージに頜食されず, 細胞間隙に長期にわたり留 まり，肉芽腫性炎を引き起こしたと考えられる。ところが，220CNTs の 4 週間後のTEM像でも確認できるように,ナノチューブ が凝集体から解けて, ライソゾームに取り达まれているTEM像 が観察されている。220-CNTsはPBS中でも, 825-CNTsより分 散性が良いため, 軟組織内での分散が可能であったため, マクロ ファージに容易に領食されたと考えられ，長さのサイズ効果が現れ ている。さらに, この原因は825-CNTs の凝集効果に加えて, ナ ノチューブの形態の影響もあると考えられる。220-CNTsは明ら かに真っすぐであるが, 825-CNTsは曲がりくねっており,ナノチ ユーブ同士が解れ難い形態をしているからである。いずれにせ よ, 今回の実験では, カーボンナノチューブは細胞が死滅するよ うな毒性の高い物質ではないことを確認した。また, 長いナノチュ ーブが凝集することでマクロファージに頜食されず, 細胞質に留 まることで肉芽腫炎など軽度の炎症を引き起こすことが確認さ れた。

まとめると, in vitroによる異物認識反応試験から, THP-1 細胞の 活性化が非常に低く, TNF- $\alpha$ が生産されにくいことから, $220 \mathrm{~nm}$

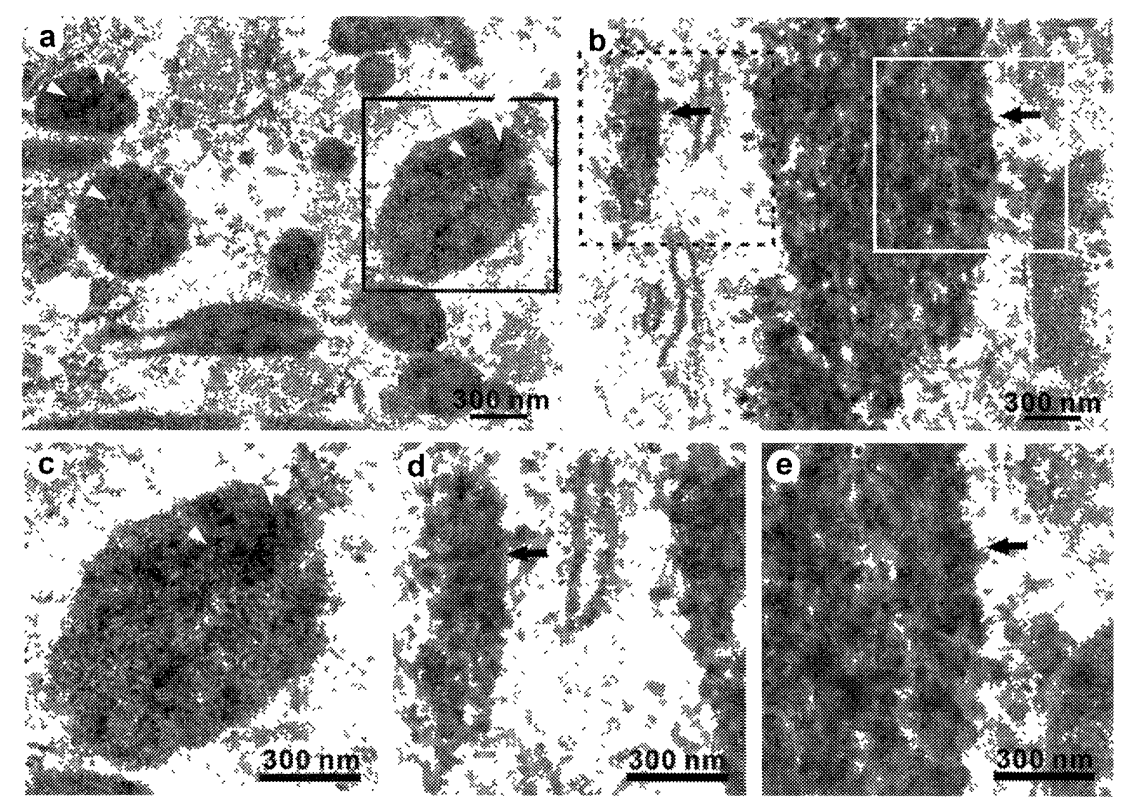

Fig.5 TEM photographs of 220-CNTs (a) and 825-CNTs (b) implanted in the subcutaneous tissue 4 weeks following surgery. Fig.5c is a high magnification TEM photograph at the black square part of Fig.5a. Figs.5d and e are high magnification TEM photographs at the black dashed square and white square part of Fig.5b. Most of the 220-CNTs (white arrowheads in Figs.5a and c) were observed in lysosomes (white arrows in Figs.5a and c). Aggregation of 825-CNTs (arrows in Figs.5b and e) was observed in the cytoplasm and was not covered by membrane. Typical structure of CNTs (white arrowheads in Figs.5b and d) was observed in the cytoplasm. All scale bars are $300 \mathrm{~nm}$. 
から $825 \mathrm{~nm}$ の範囲のナノチューブ長さでは細胞機能を害さない， 生体適合性に優れた水溶化MWCNTsであることを六した。in vivoによる周囲組織反応では, 220-CNTs は細胞人に髟入し, サイ ズの効果が観察された。また, 組織細胞は $220 \mathrm{~nm} よ り 825 \mathrm{~nm}$ の CNTs のほうが肉芽腫性炎を引き起こしたが, その炎症反応は軽 度で深刻なものではなく, 生体親和性物質であると考えられる。 本研究の結果から, カーボンナノチューブでは細胞毒性にかかわる 4つのファクター (金属含有濃度, 表面官能基, サイズと形態, 比 表面積) 以外にも, 生体内での凝集状態も重要な要因であること を示した。上記のMWCNTsを用いたスカフォールドは, ヒト骨 肉腫由来の骨芽様細胞 (Saos2) を非常によく成長させ, 人工細胞 外マトリックスとしても非常に興味深い特性を示している75),76)。

\section{4. まとめ}

さまざまな CNTs をさまざまな妈理を施して毒性試験を行うこ とは, データとして蓄積され有益なことではあるが, 使用するCNTs の詳細な情報を示さない，もしくはCNTsのキャラクタリーゼー ションを行わないのは問題である。例えば, Mullerら 58)による 「精製したMWCNTs の粉砕物」は瑪瑙ボールミルでサンプルを 調製している。筆者の経験では, 回転速度にも依存するが粉砕ポ ットとボールの材質が不純物としてサンプルに混入してしまうの で, 彼らのデータは瑪瑙の不純物の影響が現れているのではないか と疑いが生じる。瑪瑙は互層した縞状の微結晶質石英の集合体 ある。近年では, 結晶質シリカは高い発ガン性物質として位置づ けられている77)。彼らの論文では粉砕後のMWCNTsのキャラ クタリーゼーションを記述していないため, 粉砕で混入した微結 晶シリカの毒性を測定している可能性も考えられる。重要であ るのは, 使用するCNTs の詳細な情報を調べたうえでの毒性評価 を行うことである。また, 使用する細胞にも異物に対する感受性 の高い細胞もあり, 細胞によって CNTs の細胞毒性反応は十分異 なる可能性がある。さらに, 本来の CNTs の毒性を評価するにあ たり, 細胞毒性にかかわる4つのファクター (金属含有濃度, 表面 官能基, サイズと形態, 比表面積) とナノチューブの凝集状態に 関するCNTsの詳細な分析が欠けているため, 現時点ではナノチ ユーブに毒性があるのか, 毒性があるのであれば, どのような要 因から引き起こされているかなどの議論は困難である。最近, Wörle-Knirsch らは78), SWCNTs がMTTアッセイにあるテトラ ゾリウム塩と相互作用を示す知見を得ており, 従来の細胞生存率 の毒性試験方法がナノ粒子, カーボンナノチューブに適当な試験 方法であるのか考えさせるデータを揭示していると同時に, 規格化 されたカーボンナノチューブの提供により, 出発物の統一サンプ ルによる細胞毒性評価を提案している。現段階では, ある毒性試 験を行うことによって安全性を評価できるという決定的な方法 はないが, 時間を必要とするin vivo 試験は有効な毒性評価である と考える。今後, 産業におけるカーボンナノチューブが発展される ためにも, カーボンナノチューブの細胞毒性が正しく評価される ことを期待したい。

\section{謝 辞}

本研究の一部は厚生科研費（課題H18-化学- - 般-006）, 财団法 人新井科学技術振興財団助成金, および東北大学学際科学国際高 䇠研究センターのセンター其同研究によるものである。

\section{文 献}

1) R. Langer and J. P. Vacanti, Science 260 (1993) 920.

2) M. Yamato and T. Okano, Materials Today 7 (2004) 42.

3）浅島 誠, 卡田博夫, 上田 奏 編: “博生医学と生命科学一生殖工 学・幹細胞丁学・組織工学” (2000) 其立出版.

4）中林宣男, 不原一彦, 岩崎泰彦：“バイオマテリアル”(1999) コロナ社.

5）久保木芳德, 滰田裕子, 吉本良太, 贺来 亨, ティッシュエンジニアリ ング 2006 (2006) 24.

6) V. L. Gott, J. D. Whiffen and R. C. Dutton, Science 142 (1963) 1297.

7) J. C. Bokros, Carbon 15 (1977) 355.

8) A. T. Woolley, C. Guillemette, C. L. Cheung, D. E. Housman and C. M. Lieber, Nat. Biotechnol. 18 (2000) 760.

9) A. Bianco and M. Prato, Adv. Mater. 15 (2003) 1765.

10) D. Pantarotto, J. -P. Briand, M. Prato and A. Bianco, Chem. Comm. (2004) 16.

11) D. Pantarotto, C. D. Partidos, J. Hoebeke, F. Brown, E. Kramer, J. P. Briand, S. Muller, M. Prato and A. Bianco, Chem. Biol. 10 (2003) 961.

12) Q. Lu, J. M. Moore, G. Huang, A. S. Mount, A. M. Rao, L. L. Larcom and P. C. Ke, Nano Lett. 4 (2004) 2479.

13) T. Murakami, K. Ajima, J. Miyawaki, M. Yudasaka, S. Iijima and K. Shiba, Mole. Pharm. 1 (2004) 399.

14) A. Bianco, K. Kostarelos, C. D. Partidos and M. Prato, Chem. Comm. (2005) 571.

15) D. Pantarotto, R. Singh, D. McCarthy, M. Erhardt, J. P. Briand, M. Prato, K. Kostarelos and A. Bianco, Angew. Chem. Int. Ed. 43 (2004) 5242.

16) Q. Lu, J. M. Moore, G. Huang, A. S. Mount, A. M. Rao, L. L. Larcom and P. C. Ke, Nano Lett. 4 (2004) 2473.

17) B. Fugetsu, S. Satoh, T. Shiba, T. Mizutani, Y. -B, Lin, N. Terui, Y. Nodasaka, K. Sasa, K. Shimizu, T. Akasaka, M. Shindoh, K. -I. Shibata, A. Yokoyama, M. Mori, K. Tanaka, Y. Sato, K. Tohji, S. Tanaka, N. Nishi and F. Watari, Environ. Sci. Technol. 38 (2004) 6890.

18) F. Balavoine, P. Schultz, C. Richard, V. Mallouh, T. W. Ebbesen and C. Mioskowski, Angew. Chem. Int. Ed. 38 (1999) 1912.

19) M. Endo, S. Koyama, Y. Matsuda, T. Hayashi and Y. -A. Kim, Nano Lett. 5 (2005) 101.

20) C. Li, M. Curreli, H. Lin, B. Lei, F. N. Ishikawa, R. Datar, R. J. Cote, M. E. Thompson and C. Zhou, J. Am. Chem. Soc. 127 (2005) 12484.

21) M. P. Mattson, R. C. Haddon and A. M. Rao, J. Mol. Neurosci. 14 (2000) 175.

22) P. R. Supronowicz, P. M. Ajayan, K. R. Ullmann, B. P. Arulanandam, D. W. Mettzger and R. Bizios, J. Biomed. Mater. Res. 59 (2002) 499.

23) H. Hu, Y. Ni, V. Montana, R. C. Haddon and V. Parpura, Nano Lett. 4 (2004) 507.

24) M. A. Correa-Duarte, N. Wagner, J. Rojas-Chapana, C. Morsczeck, M. Thie and M. Giersig, Nano Lett. 4 (2004) 2233.

25) J. H. Rouse, P. T. Lillehei, J. Sanderson and E. J. Siochi, Chem. Mater. 16 (2004) 3904.

26) H. Hu, Y. Ni, S. K. Mandal, V. Montana, B. Zhao, R. C. Haddon and V. Parpura, J. Phys. Chem. B. 109 (2005) 4285.

27) V. Lovat, D. Pantarotto, L. Lagostena, B. Cacciari, M. Grandolfo, M. Righi, G. Spalluto, M. Prato and L. Ballerini, Nano Lett. 5 (2005) 1107.

28） A. L. Chum, J. G. Moralez, H. Fennoro and T. J. Webster, Nanotechnology 


\section{5 (2004) S234.}

29) D. Khang, M. Sato and T. J. Webster, Reviews on Advanced Materials Science 10 (2005) 205

30) L. P.Zanello, B. Zhou, H. Hu and R. C. Haddon, Nano Lett. 6 (2006) 562.

31) R. F. Service, Science 281 (1998) 941.

32) R. F. Service, Science 300 (2003) 243.

33) P. H. M. Hoet, A. Nemmar and B. Nemery, Nat. Biotechnol. 22 (2004) 19.

34) V. L. Colvin, Nat. Biotechnol. 21 (2004) 1166.

35) A. Nel, T. Xia, L. Madler and N. Li, Science 311 (2006) 622.

36) A. McNamara and D. F. Williams, Biomaterials 2 (1981) 33.

37) M. Uo,F. Watari, A. Yokoyama, H. Matsuno and T. Kawasaki, Biomaterials 22 (2001) 677.

38) B. Fubini, Environ. Health. Perspect. 105 (1997) 1013.

39) A. Hoshino, K. Fujioka, T. Oku, M. Suga, Y. F. Sasaki, T. Ohta, M. Yasuhara, K. Suzuki and K. Yamamoto, Nano Lett. 4 (2004) 2163.

40) E. E. Connor, J. Mwamuka, A. Gole, C. J. Murphy and M. D. Wyatt, Small 1 (2005) 325.

41) C. J. Johnston, J. N. Finkelstein, P. Mercer, N. Corson, R. Gelein and G. Oberdörster, Toxicol. Appl. Pharmacol. 168 (2000) 208.

42) K. Tamura, N. Takashi, R. Kumazawa, F. Watari and Y. Totsuka, Mater. Trans. 43 (2002) 3052.

43) J. E. Sanders, C. E. Stiles and C. L. Hayes, J. Biomed. Mater. Res. 52 (2000) 231.

44) A. M. Rodrigo, M. E. Martinez, M. L. Escudero, J. Ruiz, P. Martinez, L. Saldana, L. Gomez-Garcia, L. Fernandez, J. Cordero and L. Munuera, Biomaterials 22 (2001) 755.

45) R. Kumazawa, F. Watari, N. Takashi, Y. Tanimura, M. Uo and Y. Totsuka, Biomaterials 23 (2002) 3757.

46) M. Tsoli, H. Kuhn, W. Brandau, H. Esche and G. Schmid, Small 1 (2005) 841.

47) T. J. Brunner, P. Wick, P. Manser, P. Spohn, R. N. Grass, L. K. Limbach, A. Bruinink and W. J. Stark, Environ. Sci. Technol. 40 (2006) 4374.

48) T. Kodama, J. Stomatol. Soc. Jpn. 38 (1989) 263.

49) J. P. Landsberg, B. McDonald and F. Watt, Nature 360 (1992) 65.

50）神山宣彦, セラミックス 29 (1994) 111.

51) M. F. Stanton, M. Layard, A. Tegeris, E. Miller, M. May, E. Morgan and A. Smith, J. Natl. Cancer Inst. 67 (1981) 965.

52) F. Pott, IARC Sci. Pub. No.30, Vol.1, (1980) 286.

53) G. A. Hart, L. M. Kathman and T. W. Hesterberg, Carcinogenesis 15 (1994) 971.

54) A. Huczko, H. Lange, E. Calko, H. Grubek-Jaworska and P. Droszcz, Fullerene Sci. Technol. 9 (2001) 251.

55) A. Huczko, H. Lange, M. Bystrzejewski, P. Baranowski, H. GrubekJaworska, P. Nejman, T. Przybyłowski, K. Czumińska, J. Glapiński, D. R. M. Walton and H. W. Kroto, Fuller. Nanotub. Carbon Nanostruct. 13 (2005) 141.

56) D. B. Warheit, B. R. Laurence, K. L. Reed, D. H. Roach, G. A. M. Reynolds and T. R. Webb, Toxicol. Sci. 77 (2004) 117.

57) C. W. Lam, J. T. James, R. McCluskey and R. L. Hunter, Toxicol. Sci.
77 (2004) 126.

58) J. Muller, F. Huaux, N. Moreau, P. Misson, J. -F. Heilier, M. Delos, M. Arras, A. Fonseca, J. B. Nagy and D. Lison, Toxicol. Appl. Pharmacol. 207 (2005) 221.

59) A. Huczko and H. Lange, Fullerene Sci. Technol. 9 (2001) 247.

60) A. A. Shvedova and V. Castranova, J. Toxicol. Environ. Health A. 66 (2003) 1909.

61) N. A. Monteiro-Riviere, R. J. Nemanich, A. O. Inman, Y. Y. Wang and J. E. Riviere, Toxicol. Lett. 155 (2004) 377.

62) I. Fenoglio, M. Tomatis, D. Lison, J. Muller, A. Fonseca, J. B. Nagy and B. Fubini, Free Radic. Biol. Med. 40 (2006) 1227.

63) M. Bottini, S. Bruckner, K. Nika, N. Bottini, S. Bellucci, A. Magrini, A. Bergamaschi and T. Mustelin, Toxicol. Lett. 160 (2006) 121.

64) S. Koyama, M. Endo, Y. -A. Kim, T. Hayashi, T. Yanagisawa, K. Osaka, H. Koyama, H. Haniu and N. Kuroiwa, Carbon 44 (2006) 1079.

65) J. Chłopek, B. Czajkowska, B. Szaraniec, E. Frackowiak, K. Szostak and F. Béguin, Carbon 44 (2006) 1106.

66) C. M. Sayes, F. Liang, J. L. Hudson, J. Mendez, W. Guo, J. M. Beach, V. C. Moore, C. D. Doyle, J. L. West, W. E. Billups, K. D. Ausman and V. L. Colvin, Toxicol. Lett. 161 (2006) 135.

67) R. Singh, D. Pantarotto, L. Lacerda, G. Pastorin, C. Klumpp, M. Prato, A. Bianco and K. Kostarelos, Proc. Natl. Acad. Sci. U. S. A 103 (2006) 3357.

68) H. Dumortier, S. Lacotte, G. Pastorin, R. Marega, W. Wu, D. Bonifazi, J. -P. Briand, M. Prato, S. Muller and A. Bianco, Nano Lett. 6 (2006) 1522.

69) X. Chen, U. C. Tam, J. L. Czlapinski, G. S. Lee, D. Rabuka, A. Zettl and C. R. Bertozzi, J. Am. Chem. Soc. 128 (2006) 6292.

70) Y. Sato, A. Yokoyama, K. -I. Shibata, Y. Akimoto, Y. Nodasaka, T. Kohgo, K. Tamura, T. Akasaka, M. Uo, K. Motomiya, B. Jeyadevan, M. Ishiguro, R. Hatakeyama, F. Watari and K. Tohji, Mol. BioSyst. 1 (2005) 176.

71) J. Liu, A. G. Rinzler, H. Dai, J. H. Hafner, R. K. Bradley, P. J. Boul, A. Lu, T. Iverson, K. Shelimov, C. B. Huffman, F. Rodriguez-Macias, Y. S. Shon, T. R. Lee, D. T. Colbert and R. E. Smalley, Science 280 (1998) 1253.

72) Y. Sato, K. -I. Shibata, F. Bunshi, A. Yokoyama, K. Tamura, T. Akasaka, M Uo, K. Motomiya, B. Jeyadevan, R Hatakeyama, F. Watari and K. Tohji, Mol. BioSyst. 1 (2005) 142.

73) M. Ishikuro, Y. Sato, K. Tohji and K. Wagatsuma, Buniseki Kagaku 55 (2006) 117.

74) M. Sano, J. Okamura and S. Shinkai, Langmuir 17 (2001) 7172.

75) N. Aoki, A. Yokoyama, Y. Nodasaka, T. Akasaka, M. Uo, Y. Sato, K. Tohji and F. Watari, J. Biomed. Nanotechnol. 1 (2005) 402.

76) N. Aoki, A. Yokoyama, Y. Nodasaka, T. Akasaka, M. Uo, Y. Sato, K. Tohji and F. Watari, Chem. Lett. 35 (2006) 508.

77) IARC, IARC Sci. Pub. No.97 (1990).

78) J. M. Wörle-Knirsch, K. Pulskamp and H. F. Krug, Nano Lett. 6 (2006) 1261. 